\title{
Image phenotyping of lettuce germplasm with genetically diverse carotenoid levels
}

\author{
Gabriel Mascarenhas Maciel ${ }^{1}$ (D), Rodrigo Bezerra de Araújo Gallis² (D), Ricardo Luís Barbosa² (D), \\ Lucas Medeiros Pereira ${ }^{1}$ (D), Ana Carolina Silva Siquieroli ${ }^{(D)}$, Joicy Vitória Miranda Peixoto ${ }^{1^{*}}$ (D) \\ 1. Universidade Federal de Uberlândia - Instituto de Ciências Agrárias - Monte Carmelo (MG), Brazil. \\ 2. Universidade Federal de Uberlândia - Instituto de Geografia - Monte Carmelo (MG), Brazil. \\ 3. Universidade Federal de Uberlândia - Instituto de Biotecnologia - Monte Carmelo (MG), Brazil.
}

\begin{abstract}
Developing biofortified foods such as lettuce is a frequent goal of breeding programs. One obstacle to the success of these efforts is the high temporal and financial cost of determining leaf constituents. Image phenotyping has been increasingly used in crop breeding, but not in lettuce breeding. Until now, the use of image phenotyping to indirectly select carotenoid-rich lettuce inbred lines has not been reported. Therefore, the goal of this study was to use image phenotyping to select lettuce inbred lines with different carotenoid levels. Twenty-two inbred lettuce lines, resulting from the hybridization of the cultivars Pira 72 and Uberlândia 10000 and six successive selfings were evaluated. 'Grand Rapids', 'UFU-Biofort' and 'Uberlândia 10000' were used as controls. The following variables were evaluated: agronomic potential, apparent genetic diversity and image phenotyping. The data were submitted to the ANOVA F test $(p \leq 0.05)$ and means compared by the Scott-Knott test $(p \leq 0.05)$. Genetic divergence was represented by dendrograms constructed by UPGMA and the Tocher optimization method. The relative contribution of characters was assessed to identify the most relevant response variable. The genetic diversity of the evaluated germplasm bank was the greatest regarding soil plant analysis development (SPAD)/carotenoid values. Image phenotyping was successfully used to detect different levels of SPAD/carotenoid levels and could be a useful tool for plant breeding. The results of this study can be used to predict the nutritional values of the carotenoid content in lettuce leaves before commercialization.
\end{abstract}

Key words: geotechnology, biofortification, Lactuca sativa L., unmanned aerial vehicle (UAV).
Received:

Dec. 23, 2019

Accepted:

Mar 3, 2020

Section Editor:

Freddy Mora

${ }^{*}$ Corresponding author: joicyvmpeixoto@ufu.br

\section{INTRODUCTION}

Lettuce (Lactuca sativa L.) is the most consumed leafy vegetable in the world and ranks third among all vegetables in production volume. Crisphead lettuce is more economically important than iceberg, looseleaf and Romaine lettuce (Sala et al. 2008; Sala and Costa 2012). Consuming this vegetable can help prevent several diseases related to oxidative stress (Rocha and Reed 2014). Most of these health benefits are provided by carotenoids (Sousa et al. 2007; Cassetari et al. 2015), which are vitamin A precursors in vegetables (Silva and Mura 2016).

Researches have shown that carotenoid-rich lettuce inbred lines can be obtained (Sousa et al. 2007; Cassetari et al. 2015). Nevertheless, despite the relevance of biofortified foods, few studies have focused on the development of carotenoid-rich lettuce cultivars. One of the greatest obstacles to breeding carotenoid-rich lettuce inbred lines is the high cost of analyzing leaf 
constituents. Cassetari et al. (2015) observed that carotenoid levels and chlorophyll levels are highly correlated, which suggests that carotenoid content could be indirectly measured with the soil plant analysis development (SPAD) index. However, breeding programs produce thousands of inbred lines, which makes data collection very time-consuming and unfeasible.

While image phenotyping has become an increasingly important tool in the breeding of several crops (Brisson et al. 2010; Sousa et al. 2015), it has not been used in lettuce breeding. The technique is used to determine qualitative and/or quantitative values of given characteristics and correlate them with the performance of an inbred line within a specific environment (Dhondt et al. 2013). Plant phenotyping, mainly via images, is a quick, inexpensive and nondestructive tool that can be used for the optical analysis of plant characteristics (Gupta et al. 2013; Walter et al. 2015; Kyratzis et al. 2017; Maciel et al. 2019b). Plant phenomena are currently studied using several techniques including image spectroscopy (Sousa et al. 2015).

Unmanned aerial vehicles (UAV), also known as drones, can collect high-resolution (spatial and temporal) images that allow nearly real-time monitoring of field experiments. These aircrafts can be equipped with various types of sensors that capture spectra ranging from visible electromagnetic to infrared and can be used in various analyses of vegetation (Sousa et al. 2015; Yang et al. 2017). The high spatial and temporal resolutions provided by this technology are among the main reasons for using it in lettuce phenotyping.

While several studies have sought to correlate the reflectance of vegetation canopies with the characteristics of several plant species (Johann et al. 2012; Risso et al. 2012; Makanza et al. 2018), this approach has not been used with vegetable crops. Until now, no studies have used image phenotyping to aid in the indirect selection of carotenoid-rich lettuce inbred lines. Therefore, the objective of the current study was to use this technique to select lettuce inbred lines with agronomic potential and different levels of carotenoids.

\section{MATERIAL AND METHODS}

The experiment was carried out in 2018 at the Estação Experimental de Hortaliças (Vegetable Experiment Station) of the Universidade Federal de Uberlândia (UFU), campus Monte Carmelo (Federal University of Uberlândia, Monte Carmelo campus) (18²'43,19'S, 47²9’55, $8^{\prime \prime}$ W, 873 m altitude), which is a component of UFU's Biofortified Lettuce Breeding Program.

Twenty-two lettuce inbred lines were evaluated. These resulted from hybridizations of cultivars Pira 72 and the carotenoidrich Uberlândia 10000 (Sousa et al. 2007), followed by six successive selfings (2013-2017). They were obtained through genealogical breeding. The lines belonged to the biofortified lettuce germplasm bank of the UFU (Maciel et al. 2019a). Three cultivars were used as controls: Grand Rapids, UFU-Biofort and Uberlândia 10000, totaling 25 genotypes.

Sowing took place on March 28, 2018. The seedlings were produced in 200-cell expanded polystyrene trays filled with a commercial coconut fiber substrate. After sowing, the trays were maintained in a hoop-style greenhouse (area: $5 \times 6 \mathrm{~m}$, height: $3.5 \mathrm{~m}$ ) that was covered with UV resistant polyethylene film $(150 \mu)$ and anti-aphid side screens. At 29 days after sowing the seedlings were transplanted to beds in the field that had been prepared with a rototiller-hiller ( $1.3 \mathrm{~m}$ wide).

Soil analysis showed the following: $\mathrm{pH}\left(\mathrm{H}_{2} \mathrm{O}\right)=5.9$; available $\mathrm{P}=30.1 \mathrm{mg} \cdot \mathrm{dm}^{-3} ; \mathrm{K}^{+}=0.22 \mathrm{cmolc} \cdot \mathrm{dm}^{-3} ; \mathrm{Ca}^{+2}=2.8 \mathrm{cmolc} \cdot \mathrm{dm}^{-3}$; $\mathrm{Mg}=1.0 \mathrm{cmolc} \cdot \mathrm{dm}^{-3}$; exchangeable $\mathrm{H}^{+} \mathrm{Al}=3.40 \mathrm{cmolc} \cdot \mathrm{dm}^{-3}$; organic matter = $4.2 \mathrm{dag} \cdot \mathrm{Kg}^{-1} ; \mathrm{SMP}$ index = 3.40; aluminum = $0.0 \mathrm{cmolc} \cdot \mathrm{dm}^{-3} ; \mathrm{CEC} \mathrm{pH} 7.0=7.42 \mathrm{cmolc} \cdot \mathrm{dm}^{-3} ; \mathrm{CEC}$ base sat $\mathrm{pH} 7.0=54 \%$; Al sat of effective $\mathrm{CEC}=0 \%$; copper $=2.3 \mathrm{mg} \cdot \mathrm{dm}^{-3}$; zinc $=6.6 \mathrm{mg} \cdot \mathrm{dm}^{-3}$ and manganese $=6.6 \mathrm{mg} \cdot \mathrm{dm}^{-3}$. Crop treatments were carried out as recommended for lettuce (Filgueira 2013).

Each experimental plot (Fig. 1) consisted of 16 plants in four rows (spaced $0.25 \times 0.25 \mathrm{~m}$ ), of which only the eight centermost plants were evaluated. The plants were harvested 35 days after transplant and taken to a laboratory where total fresh mass was determined by weighing all external leaves except those smaller than $5 \mathrm{~cm}$ long. Stem diameter was measured with a pachymeter and the number of commercially viable leaves was determined by counting leaves greater than $5 \mathrm{~cm}$ long. Plant diameter was measured and expressed in centimeters. Leaf temperature was determined by aiming an infrared thermometer (model 4000.4GL, Everest Interscience, Tucson, AZ, USA) at the center of the uppermost leaf. Total anthocyanin content was determined using the method described by Francis (1982). Anthocyanin pigment concentration was calculated

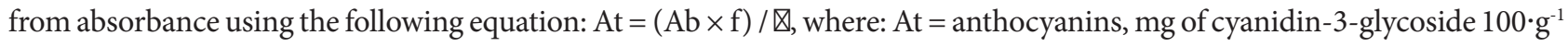
of fresh mass; $\mathrm{Ab}=$ absorbance; $\mathrm{f}=$ the dilution factor; $\mathbb{\nabla}=$ the molar absorptivity coefficient of cyanidin (98.2). The results 


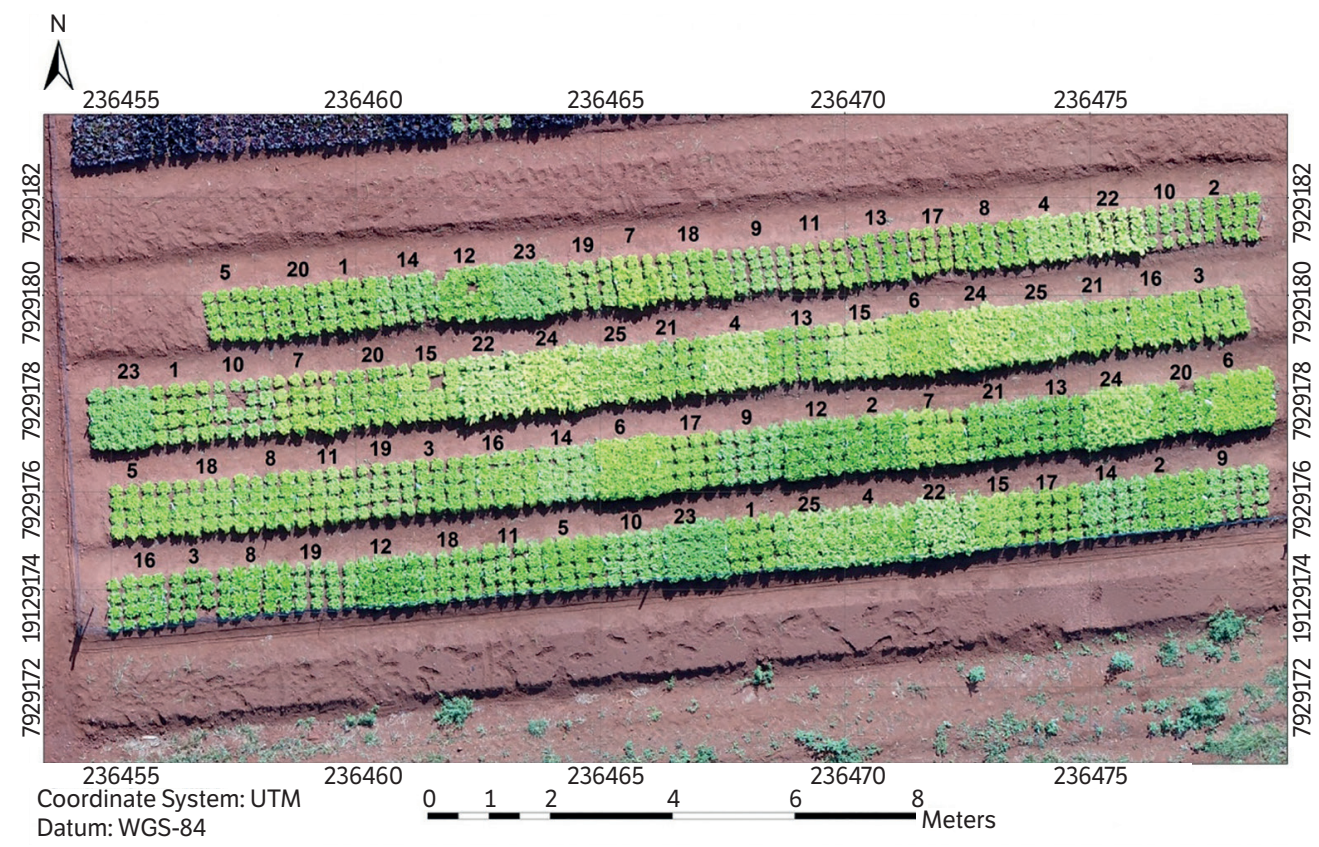

GSD $-1.00 \mathrm{~cm}$

Legend: 1: UFU-206\#1\#6\#1; 2: UFU-189\#3\#1\#1; 3: UFU-197\#3\#1\#1; 4: UFU-125\#1\#1\#1; 5: UFU-7\#1\#2\#1; 6: UFU-155\#1\#1\#1; 7: UFU-120\#1\#1\#1; 8: UFU189\#1\#2\#1; 9: UFU-197\#2\#1\#1; 10: UFU-199\#3\#1\#1; 11: UFU-206\#1\#1\#1; 12: UFU-206\#3\#1\#1; 13: UFU-197\#1\#1; 14: UFU-197\#2\#2\#1; 15: UFU-155\#1\#2\#1; 16: UFU-189\#3\#4\#1; 17: UFU-206\#1\#4\#1; 18: UFU-125\#2\#2\#1; 19: UFU-206\#1\#2\#1; 20: UFU-189\#3\#2\#1; 21: UFU-206\#1\#5\#1; 22: UFU-040\#5\#5\#1; 23: 'UFU Biofort'; 24: 'Grand Rapids'; 25: ‘Uberlândia 10000'

Figure 1. Orthoimage of the experiment.

were expressed in $\mathrm{mg}$ of cyanidin-3-glycoside $100 \cdot \mathrm{g}^{-1}$ of fresh mass. The SPAD/carotenoid index (Cassetari et al. 2015) was calculated as the mean of the measures from the four central plants of each plot. These measurements were taken with a chlorophyllometer (Minolta SPAD-502 CFL1030). The number of days from sowing to bolting (DBS) were also recorded.

The data were submitted to the ANOVA F test $(\mathrm{p}<0.05)$ and the means were compared by the Scott-Knott test $(\mathrm{p}<0.05)$. Next, multivariate analyses of genetic dissimilarity between inbred lines were carried out using the Mahalanobis generalized distance $\left(\Delta_{\mathrm{ii}}^{2}\right)$. Genetic divergence was represented by dendrograms that were obtained using the unweighted pair-group method using arithmetic averages (UPGMA) and Tocher optimization. The UPGMA clustering was validated using a cophenetic correlation coefficient (CCC) calculated by the Mantel test Mantel (1967). The relative contribution of the quantitative traits was calculated according to Singh (1981). All data were analyzed using Genes software (version 2015.5.0) (Cruz 2013).

In addition to using conventional methodology based on the SPAD/carotenoid index (Cassetari et al. 2015), image phenotyping of the same inbred lines was performed using aerial images taken with a 20-megapixel RGB camera with a CMOS sensor and a 9-mm focal length and mounted on a Phantom 4 unmanned aerial vehicle (UAV). The images were collected at $4864 \times 3648 \mathrm{px}$ and stored as JPEGs.

The flight parameters were: 20 -m height, $80 \%$ longitudinal overlap and $75 \%$ lateral overlap. The flight was performed automatically using the proprietary DroneDeploy software. The resulting images were used to generate an orthophoto with a ground sample distance (GSD) of $1 \mathrm{~cm}$ (Pix $4 \mathrm{~d}$ software). A histogram (green channel) was calculated for the images for the two most contrasting lines in the SPAD/carotenoid index. Each plot was manually delimited in the orthophoto and ImageJ v. 1.52 software was used to isolate the green channel RGB image.

Mean values of green intensity $(G)$ were calculated for each plot. Subsequently, the Pearson correlation between the SPAD/ carotenoid indices and the mean green channel intensity (G) (SIGMA PLOT software, 5\% significance), were determined.

A heat map was created using an orthophoto to georeference the four plants in each useful area. Then, using the average value obtained by SPAD, interpolation was performed to obtain the result from each useful area to the entire plot. In addition to the correlation, QGis software (v. 3.0) was used to visualize the geospatial distribution of the SPAD/carotenoid index in a heat map generated using the inverse distance weighted (IDW) function as a kernel. 


\section{RESULTS}

\section{Agronomic evaluation of the germplasm}

During the evaluation period (March-June), maximum temperatures ranged from 18.8 to $32.8{ }^{\circ} \mathrm{C}$ (mean $=28.1{ }^{\circ} \mathrm{C}$ ) while minimum temperatures varied from 5.7 to $20.9^{\circ} \mathrm{C}\left(\right.$ mean $=16.8^{\circ} \mathrm{C}$ ) (SISMET 2018). These temperatures were outside the optimal range for lettuce cultivation, which is 4 to $27^{\circ} \mathrm{C}$ (Santos et al. 2009).

The lettuce inbred lines were significantly different from each other $(\mathrm{F}$ test, $\mathrm{p} \leq 0.05)$ for all variables except leaf temperature and anthocyanin content (Table 1). UFU-155\#1\#1\#1 had the highest fresh mass $(277.7 \mathrm{~g}$ ) of all the inbred lines and did not differ significantly from the commercial cultivars UFU-Biofort, Grand Rapids and Uberlândia 10000 (267.2,313.4 and 275.4 g, respectively) (Table 1).

The stem diameters of UFU-189\#3\#1\#1, UFU-197\#3\#1\#1, UFU-125\#1\#1\#1, UFU-155\#1\#1\#1, UFU-197\#2\#1\#1, UFU206\#3\#1\#1, UFU-197\#1\#1, UFU-197\#2\#2\#1, UFU-155\#1\#2\#1, UFU-189\#3\#4\#1, UFU-206\#1\#4\#1, UFU-189\#3\#2\#1, UFU206\#1\#5\#1 and UFU-040\#5\#5\#1 were similar to those of the controls 'Grand Rapids' and 'Uberlândia 10000' (Table 1).

Table 1. Mean fresh mass (FM), stem diameter (SD), leaf number (LN), plant diameter (PD), leaf temperature (LT), anthocyanin content (AC), days to bolting after sowing (DBS) and the SPAD/carotenoid index (carotenoid), of crisphead lettuce inbred lines.

\begin{tabular}{|c|c|c|c|c|c|c|c|c|c|}
\hline Treatments $^{1}$ & $F M(g)$ & $\mathrm{SD}(\mathrm{cm})$ & LN & PD (cm) & LT $\left({ }^{\circ} \mathrm{C}\right)$ & $A C$ & DBS (days) & carotenoid & $\mathrm{RS}^{2}(\%)$ \\
\hline UFU-206\#1\#6\#1 & $220.1 b$ & $2.0 \mathrm{~b}$ & $18.0 \mathrm{c}$ & $25.4 \mathrm{c}$ & $20.0 \mathrm{a}$ & $19.1 \mathrm{a}$ & $68.7 c$ & $22.8 \mathrm{c}$ & 30.87 \\
\hline UFU-189\#3\#1\#1 & $180.8 \mathrm{c}$ & $2.3 a$ & $25.1 \mathrm{a}$ & $24.4 \mathrm{c}$ & $19.5 \mathrm{a}$ & $22.1 \mathrm{a}$ & $88.0 \mathrm{~b}$ & $26.6 \mathrm{~b}$ & 52.29 \\
\hline UFU-197\#3\#1\#1 & $144.2 \mathrm{c}$ & $2.3 a$ & $16.9 \mathrm{c}$ & $24.6 c$ & $18.4 \mathrm{a}$ & $20.1 \mathrm{a}$ & $81.7 \mathrm{~b}$ & $22.8 \mathrm{c}$ & 30.76 \\
\hline UFU-125\#1\#1\#1 & $196.2 \mathrm{c}$ & $2.5 \mathrm{a}$ & $22.1 \mathrm{~b}$ & $24.9 c$ & $19.9 \mathrm{a}$ & $14.5 \mathrm{a}$ & $82.7 \mathrm{~b}$ & $17.0 \mathrm{f}$ & -2.52 \\
\hline UFU-7\#1\#2\#1 & $196.4 \mathrm{c}$ & $1.9 \mathrm{~b}$ & $24.4 b$ & $24.2 c$ & $20.3 a$ & $16.8 \mathrm{a}$ & $94.7 \mathrm{a}$ & $23.4 \mathrm{c}$ & 34.19 \\
\hline UFU-155\#1\#1\#1 & 277.7 a & $2.5 \mathrm{a}$ & $26.0 \mathrm{a}$ & $30.5 \mathrm{a}$ & $19.3 \mathrm{a}$ & $16.6 \mathrm{a}$ & $64.0 \mathrm{~d}$ & $16.8 \mathrm{f}$ & -4.01 \\
\hline UFU-120\#1\#1\#1 & $165.6 \mathrm{c}$ & $2.2 \mathrm{~b}$ & $17.3 \mathrm{c}$ & $25.2 \mathrm{c}$ & $19.1 \mathrm{a}$ & $12.3 \mathrm{a}$ & $71.0 \mathrm{c}$ & $15.0 \mathrm{f}$ & -14.15 \\
\hline UFU-189\#1\#2\#1 & $139.0 \mathrm{c}$ & $2.1 \mathrm{~b}$ & $26.3 \mathrm{a}$ & $23.6 c$ & $18.5 \mathrm{a}$ & $13.1 \mathrm{a}$ & $87.0 \mathrm{~b}$ & $26.8 \mathrm{~b}$ & 53.26 \\
\hline UFU-197\#2\#1\#1 & $134.8 \mathrm{c}$ & $2.3 a$ & $23.2 b$ & $24.2 c$ & $19.8 \mathrm{a}$ & $19.4 \mathrm{a}$ & $104.0 \mathrm{a}$ & $23.2 \mathrm{c}$ & 32.93 \\
\hline UFU-199\#3\#1\#1 & $127.3 \mathrm{c}$ & $1.9 \mathrm{~b}$ & $20.5 c$ & $22.7 c$ & $20.6 a$ & $19.2 \mathrm{a}$ & $87.3 \mathrm{~b}$ & $23.1 \mathrm{c}$ & 32.30 \\
\hline UFU-206\#1\#1\#1 & $172.2 \mathrm{c}$ & $2.0 \mathrm{~b}$ & $18.4 \mathrm{c}$ & $23.1 \mathrm{c}$ & $19.4 \mathrm{a}$ & $16.9 \mathrm{a}$ & $80.0 \mathrm{~b}$ & $21.3 d$ & 21.76 \\
\hline UFU-206\#3\#1\#1 & $220.7 b$ & $2.5 \mathrm{a}$ & $27.7 \mathrm{a}$ & $24.3 c$ & $20.9 a$ & $12.4 \mathrm{a}$ & $77.0 \mathrm{c}$ & $29.7 a$ & 69.93 \\
\hline UFU-197\#1\#1 & $148.2 \mathrm{c}$ & $2.3 a$ & $25.4 \mathrm{a}$ & $23.3 c$ & $20.9 a$ & $13.7 a$ & $94.7 a$ & $26.6 \mathrm{~b}$ & 52.06 \\
\hline UFU-197\#2\#2\#1 & $155.3 c$ & $2.5 \mathrm{a}$ & $22.0 \mathrm{~b}$ & $24.1 \mathrm{c}$ & $20.3 a$ & $20.2 \mathrm{a}$ & $96.0 \mathrm{a}$ & $24.1 \mathrm{c}$ & 37.86 \\
\hline UFU-155\#1\#2\#1 & $244.0 \mathrm{~b}$ & $2.5 \mathrm{a}$ & $19.8 \mathrm{c}$ & $26.2 \mathrm{~b}$ & $20.9 a$ & $17.0 a$ & $89.3 b$ & $16.1 \mathrm{f}$ & -8.08 \\
\hline UFU-189\#3\#4\#1 & $172.9 \mathrm{c}$ & $2.5 \mathrm{a}$ & $24.3 b$ & $23.7 c$ & $18.1 \mathrm{a}$ & $21.0 \mathrm{a}$ & $85.7 b$ & $26.1 \mathrm{~b}$ & 49.54 \\
\hline UFU-206\#1\#4\#1 & $186.9 \mathrm{c}$ & $2.4 \mathrm{a}$ & $15.9 c$ & $23.2 \mathrm{c}$ & $19.9 \mathrm{a}$ & $15.7 \mathrm{a}$ & $78.3 c$ & $20.5 d$ & 17.30 \\
\hline UFU-125\#2\#2\#1 & $143.3 c$ & $2.0 \mathrm{~b}$ & $23.7 \mathrm{~b}$ & $22.2 \mathrm{c}$ & $20.6 a$ & $14.7 \mathrm{a}$ & $89.7 b$ & $22.5 \mathrm{c}$ & 28.75 \\
\hline UFU-206\#1\#2\#1 & $164.9 \mathrm{c}$ & $2.0 \mathrm{~b}$ & $14.9 \mathrm{c}$ & $21.5 c$ & $19.5 \mathrm{a}$ & $17.5 \mathrm{a}$ & $74.0 \mathrm{c}$ & $21.4 \mathrm{~d}$ & 22.62 \\
\hline UFU-189\#3\#2\#1 & $185.6 \mathrm{c}$ & $2.3 a$ & $25.1 \mathrm{a}$ & $25.9 \mathrm{~b}$ & $21.2 \mathrm{a}$ & $17.5 \mathrm{a}$ & $90.7 \mathrm{~b}$ & $24.1 \mathrm{c}$ & 37.86 \\
\hline UFU-206\#1\#5\#1 & $239.8 \mathrm{~b}$ & $2.6 \mathrm{a}$ & $17.2 \mathrm{c}$ & $23.7 c$ & $19.4 \mathrm{a}$ & $20.0 \mathrm{a}$ & $72.0 \mathrm{c}$ & $25.4 \mathrm{~b}$ & 45.70 \\
\hline UFU-040\#5\#5\#1 & $176.3 \mathrm{c}$ & $2.3 a$ & $18.5 \mathrm{c}$ & $27.5 b$ & $19.0 \mathrm{a}$ & $15.2 \mathrm{a}$ & $53.0 \mathrm{e}$ & $18.9 \mathrm{e}$ & 8.02 \\
\hline UFU-Biofort & $267.2 \mathrm{a}$ & $2.0 \mathrm{~b}$ & $16.1 \mathrm{c}$ & $27.7 \mathrm{~b}$ & $21.2 \mathrm{a}$ & $19.8 \mathrm{a}$ & $81.0 \mathrm{~b}$ & $28.6 \mathrm{a}$ & 63.46 \\
\hline 'Grand Rapids' & $313.4 \mathrm{a}$ & $2.6 \mathrm{a}$ & $17.5 \mathrm{c}$ & $29.8 \mathrm{a}$ & $19.9 \mathrm{a}$ & $23.0 \mathrm{a}$ & $64.0 \mathrm{~d}$ & $17.5 \mathrm{f}$ & 0.00 \\
\hline ‘Uberlândia 10000’ & $275.4 \mathrm{a}$ & $2.2 \mathrm{a}$ & $28.5 \mathrm{a}$ & $26.9 \mathrm{~b}$ & $20.2 a$ & $18.2 \mathrm{a}$ & $83.0 \mathrm{~b}$ & $19.0 \mathrm{e}$ & 8.53 \\
\hline Overall average & 193.9 & 2.3 & 21.4 & 24.9 & 19.9 & 17.4 & 81.5 & 22.4 & 30.87 \\
\hline $\mathrm{CV}(\%)$ & 18.86 & 12.27 & 9.77 & 7.98 & 8.38 & 28.84 & 6.76 & 6.27 & 52.29 \\
\hline
\end{tabular}

${ }^{1}$ Means followed by different letters within a column differ by the Scott-Knott test $(p=0.05) .{ }^{2}$ Relative superiority (RS) of a lettuce inbred line over the control cultivar Grand Rapids, regarding the SPAD index. 
UFU-189\#3\#1\#1, UFU-155\#1\#1\#1, UFU-189\#1\#2\#1, UFU-206\#3\#1\#1, UFU-197\#1\#1 and UFU-189\#3\#2\#1 had the highest leaf numbers $(25.1,26.0,26.3,27.7,25.4$ and 25.1 leaves, respectively), which were similar to those of the carotenoidrich (Sousa et al. 2007) 'Uberlândia 10000' (28.5 leaves) and greater than that of 'Grand Rapids' (17.5 leaves) (Scott-Knott, $\mathrm{p} \leq 0.05)$ (Table 1). The UFU-155\#1\#1\#1 line had the greatest diameter $(30.5 \mathrm{~cm})$ among the various lines in this study and did not differ from 'Grand Rapids' $(29.8 \mathrm{~cm}$ ) (Scott-Knott, $\mathrm{p}=0.05)$. The inbred lines UFU-7\#1\#2\#1, UFU-197\#2\#1\#1, UFU-197\#1\#1 and UFU-197\#2\#2\#1 bolted later than the other inbred lines (Table 1).

The UFU-206\#3\#1\#1 line had the highest SPAD/carotenoid index (29.7), which was 69.93\% greater than that of 'Grand Rapids' (Table 1). The cultivar UFU-Biofort also had a high SPAD/carotenoid index (28.6), which was 63.46\% higher than that of 'Grand Rapids'. The SPAD/Carotenoid levels of UFU-189\#3\#1\#1 (26.6), UFU-189\#1\#2\#1 (26.8), UFU-197\#1\#1 (26.6), UFU-189\#3\#4\#1 (26.1) and UFU-206\#1\#5\#1 (25.4) were also higher than 'Grand Rapids' (relative superiority, RS = 52.29, $53.26,52.06,49.54$ and $45.70 \%$, respectively) (Table 1 ).

\section{Genetic diversity of the germplasm bank}

In addition to comparisons of agronomic performance (Table 1), plant breeders may also be interested in separating inbred lines into distinct groups based on dissimilarity measures (Araújo et al. 2016). The genetic dissimilarity measures (based on the Mahalanobis generalized distance, $\nabla_{\mathrm{ii}}^{2}$ ) among the 25 treatments ranged from 2.5 (UFU-189\#3\#1\#1) to 227.3 (UFU-197\#1\#1), indicating broad genetic diversity.

The groups in the UPGMA dendrogram (Fig. 2) had a significant cophenetic correlation coefficient of 0.83 ( $t$-test, $\mathrm{p}<0.01$ ). Thus, the dendrogram satisfactorily reflected the matrix data and groups. The groups were separated by a $30 \%$ cutoff line, which was established at points of abrupt change in the branches of the dendrogram (Cruz et al. 2014). This cutoff yielded seven distinct groups. Group I comprised 40\% of the inbred lines, group II 4\%, group III 4\%, group IV $24 \%$, group V 12\%, group VI 12\% while group VII contained only the commercial cultivar Grand Rapids. Thus, the germplasm in this study is genetically diverse.

The Tocher method also showed genetic diversity; however, the results were not consistent with those of the UPGMA method. The Tocher method yielded eight distinct groups (Table 2).

The SPAD/carotenoid index (Cassetari et al. 2015) provided the greatest relative contribution to divergence among the inbred lines (35.84\% of total variability) (Table 3). This was confirmed by comparing the highest (29.7) and lowest (15.0) SPAD/Carotenoid index values (Table 1). Leaf number was the second most important response variable, contributing $23.81 \%$

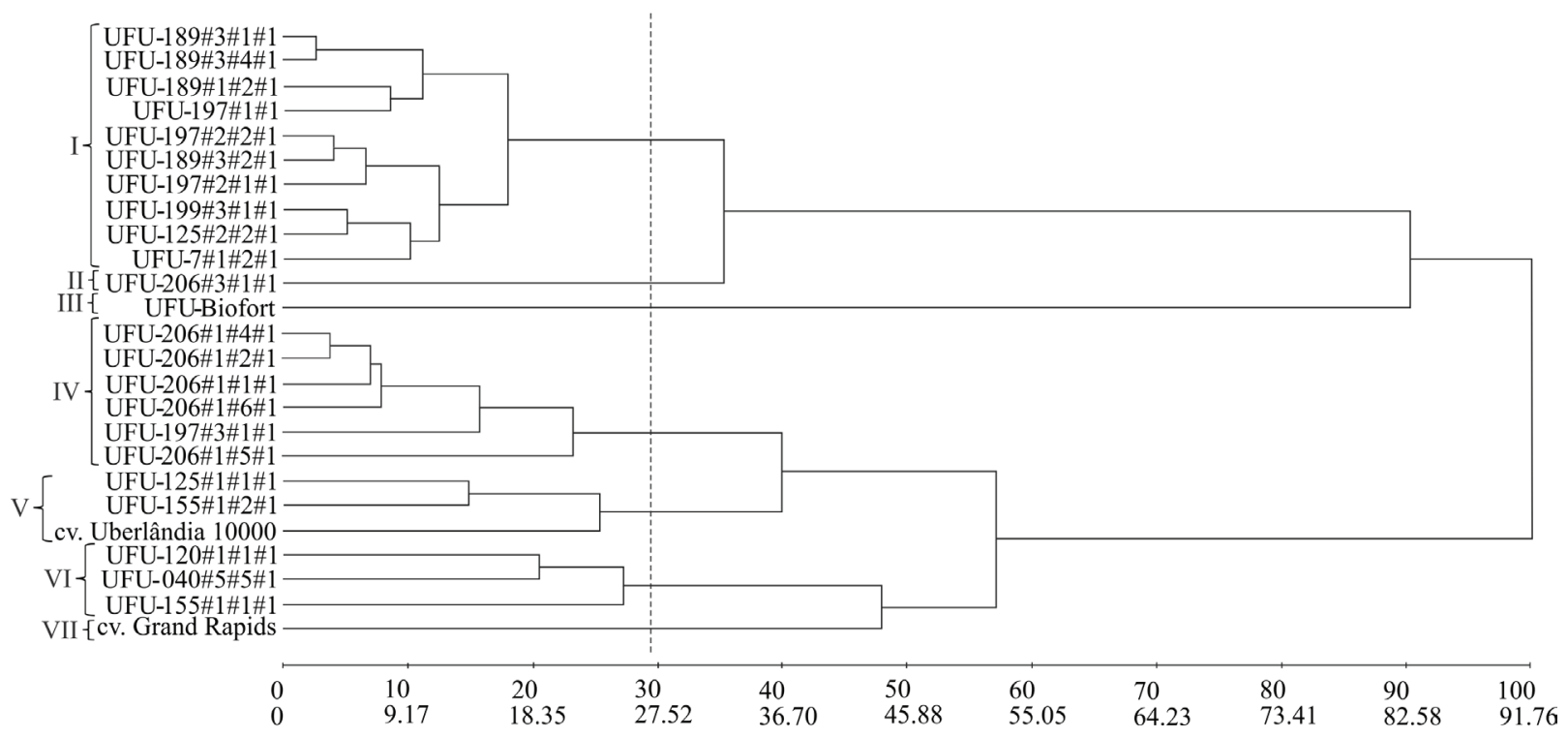

Figure 2. Dendrogram of genetic divergence among lettuce inbred lines obtained using the UPGMA hierarchical method as a measure of dissimilarity. 
Table 2. Tocher groupings estimated for eight agronomic characteristics.

\begin{tabular}{|c|c|}
\hline Groups & Individuals \\
\hline I & 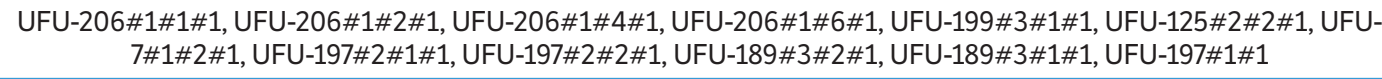 \\
\hline II & UFU-125\#1\#1\#1, UFU-155\#1\#2\#1, 'Uberlândia 10000’ \\
\hline III & UFU-197\#3\#1\#1, UFU-189\#3\#4\#1, UFU-206\#1\#5\#1 \\
\hline IV & UFU-120\#1\#1\#1, UFU-040\#5\#5\#1 \\
\hline V & UFU-155\#1\#1\#1, 'Grand Rapids' \\
\hline VI & 'UFU-Biofort' \\
\hline VII & UFU-206\#3\#1\#1 \\
\hline VIII & UFU-189\#1\#2\#1 \\
\hline Total & 25 lettuce genotypes \\
\hline
\end{tabular}

Table 3. Relative contribution of eight agronomic characters on genetic divergence in 25 treatments (Singh, 1981).

\begin{tabular}{ccc}
\hline Characters $^{1}$ & S.j & Value (\%) \\
\hline FM & 2182.06 & 11.39 \\
\hline SD & 338.56 & 1.76 \\
\hline LN & 4559.97 & 23.81 \\
\hline PD & 351.38 & 1.83 \\
\hline LT & 340.08 & 1.77 \\
\hline SPAD/carotenoid & 6864.18 & 35.84 \\
\hline AC & 249.56 & 1.30 \\
\hline DBS & 4264.71 & 22.26 \\
\hline
\end{tabular}

'FM: fresh mass ( $\mathrm{g})$, SD: stem diameter (cm), LN: leaf number, PD: plant diameter ( $\mathrm{cm})$, LT: leaf temperature $\left({ }^{\circ} \mathrm{C}\right), \mathrm{SPAD} / \mathrm{carotenoid}$ : SPAD/carotenoid index, $\mathrm{AC}$ : anthocyanin content ( $\mathrm{mg}$ of cyanidin-3-glycoside $100 \mathrm{~g}^{-1}$ of fresh mass), DBS: days to bolting after sowing.

of genetic variability. The third most important variable was the number of days between sowing and bolting (22.26\%), indicating that there was variability among the inbred lines and cultivars regarding their adaptation to tropical conditions. Conversely, stem diameter contributed only $1.76 \%$, suggesting homogeneity (Table 3 ).

\section{Image phenotyping to identify genetic diversity regarding SPAD/carotenoid levels}

The applicability of image phenotyping was determined by first confirming genetic variability among the inbred lines. Table 1 shows strong variability, especially regarding the SPAD/carotenoid index, which differed by 14.7 between extremes. The UPGMA dendrogram in Fig. 2 and the Tocher dendrogram in Table 2 confirm the genetic variability of the germplasm bank. These results were used to identify that the SPAD/carotenoid index (Table 3) was the most significant individual contributor to genetic diversity among the inbred lines. Therefore, the SPAD/carotenoid index was used to create an orthoimage (Fig. 1) and an interpolated heat map (Fig. 3) and to determine the correlation between the SPAD/carotenoid index and mean green $(\mathrm{G})$ channel intensity.

The color scale in the heat map, which was produced by interpolating the means of the SPAD/carotenoid index, ranges from cooler tones (lowest values SPAD/carotenoid index are blue) to warmer tones (highest values SPAD/carotenoid index are red) (Fig. 3).

The histogram in Fig. 4 shows that UFU-206\#3\#1\#1 and UFU-120\#1\#1\#1 had the highest and lowest values for the SPAD/carotenoid index, respectively. The SPAD/carotenoid index value of UFU-206\#3\#1\#1 (29.7) (Table 1) corresponded to a mean intensity of 192.43 in the green channel while the SPAD/carotenoid index value of UFU-120\#1\#1\#1 (15.0) corresponded to a mean intensity of 224.63 in the green channel (Fig. 4).

Tabulating the mean grayscale values from the histograms of these contrasting lines (UFU-206\#3\#1\#1 and UFU$120 \# 1 \# 1 \# 1$ ) shows that the highest and lowest SPAD/carotenoid index values were repeated in the grayscale values, but 


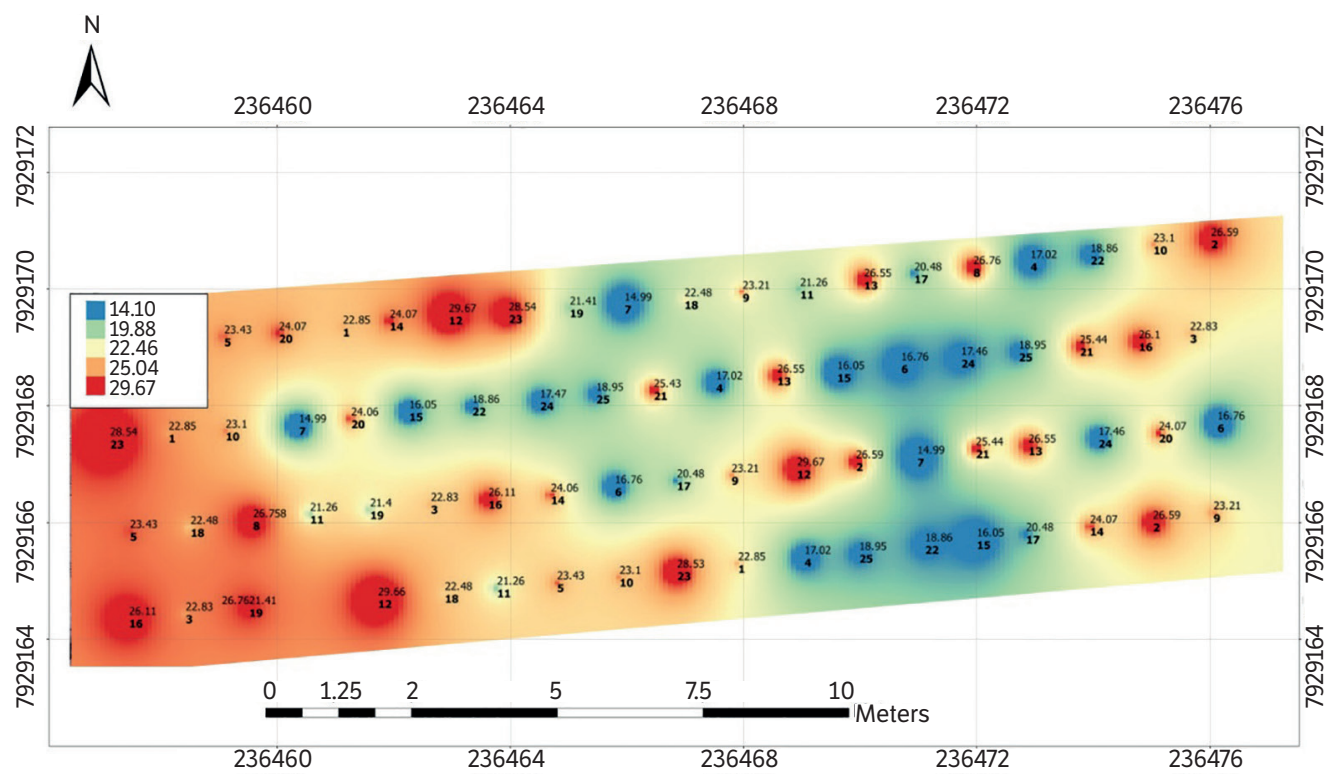

Coordinate System: UTM

Datum: WGS-84

Legend: 1: UFU-206\#1\#6\#1; 2: UFU-189\#3\#1\#1; 3: UFU-197\#3\#1\#1; 4: UFU-125\#1\#1\#1; 5: UFU-7\#1\#2\#1; 6: UFU-155\#1\#1\#1; 7: UFU-120\#1\#1\#1; 8: UFU189\#1\#2\#1; 9: UFU-197\#2\#1\#1; 10: UFU-199\#3\#1\#1; 11: UFU-206\#1\#1\#1; 12: UFU-206\#3\#1\#1; 13: UFU-197\#1\#1; 14: UFU-197\#2\#2\#1; 15: UFU-155\#1\#2\#1; 16: UFU-189\#3\#4\#1; 17: UFU-206\#1\#4\#1; 18: UFU-125\#2\#2\#1; 19: UFU-206\#1\#2\#1; 20: UFU-189\#3\#2\#1; 21: UFU-206\#1\#5\#1; 22: UFU-040\#5\#5\#1; 23: 'UFU Biofort'; 24: 'Grand Rapids'; 25: ‘Uberlândia 10000'.

Figure 3. Heat map with interpolated SPAD/carotenoid index values of the inbred lines and cultivars.
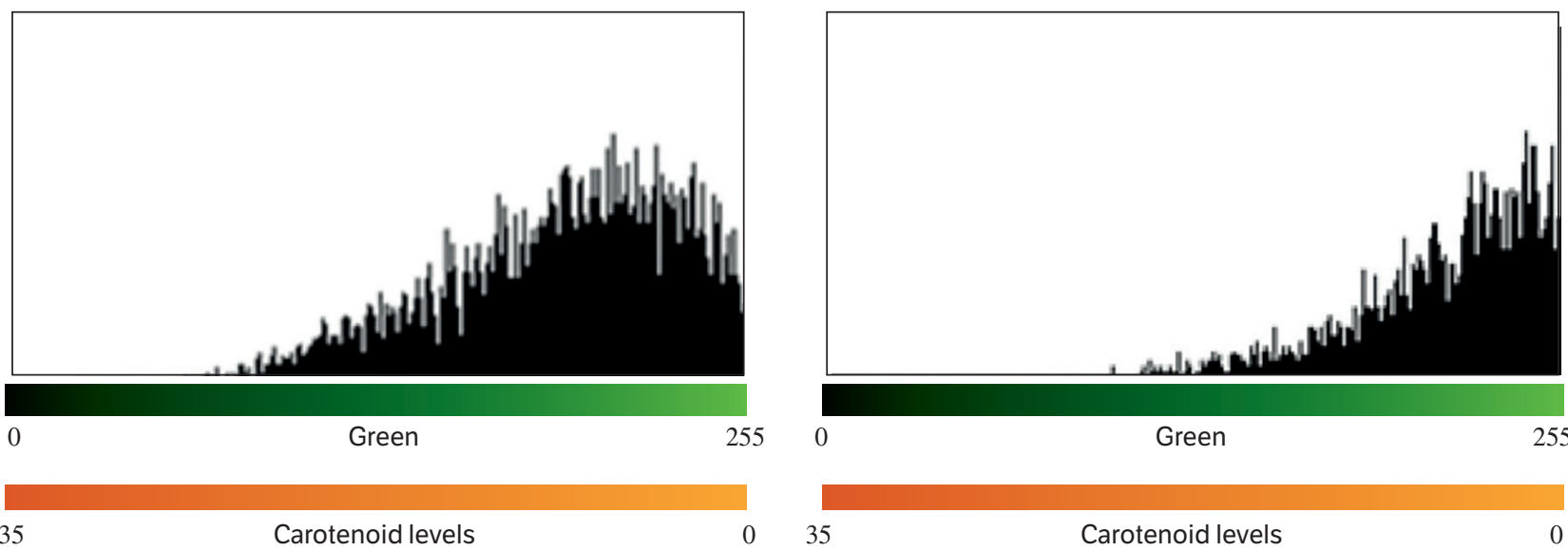

Figure 4. Histogram of the SPAD/carotenoid index for the carotenoid-rich UFU-206\#3\#1\#1 inbred line (left). Histogram of the SPAD/carotenoid index of the UFU-120\#1\#1\#1 inbred line with the lowest carotenoid level (right).

in reverse. UFU-206\#3\#1\#1 had the lowest grayscale value (darkest color in the green band) while UFU-120\#1\#1\#1 had the brightest value in the green channel (lightest color) (Fig. 4).

The regression equation $\mathrm{G}=-0.442 \times \operatorname{SPAD}+116.390\left(\mathrm{R}^{2}=0.939\right)$ was fit to model the association between the SPAD/ carotenoid index and intensity of response in the green channel (G-channel intensity). The correlation coefficient between the SPAD/carotenoid index and G-channel intensity was a very high 0.969 .

\section{DISCUSSION}

Plant breeding plays an important role in the search for biofortified foods. The antioxidant activity of carotenoids, a precursor to vitamin A (Alós et al. 2016), is important for human health and nutrition. The temporal and financial costs of 
determining the levels of this substance in leafy vegetables and fruits are often prohibitive (Kimura and Rodriguez-Amaya 2002). However, aerial imaging may provide a viable alternative for selecting carotenoid-rich lettuce lines.

The use of aerial sensing for phenotyping is fast, objective (lacking the subjectivity of human evaluation), noninvasive, relatively inexpensive and effective (Gupta et al. 2013; Zaman-Allah et al. 2015; Kyratzis et al. 2017; Tripodi et al. 2018; Maciel et al. 2019b). This technique reduces the time needed to collect field data, which means that larger samples can be evaluated, yielding more reliable results.

The present study identified and confirmed the genetic diversity of 25 lettuce genotypes. Image phenotyping was then used to indirectly select carotenoid-rich lettuce. Carotenoid levels were determined from SPAD/carotenoid index as described by Cassetari et al. (2015). Next, aerial images of these genotypes were phenotyped. While geotechnologies have already been successfully used in studies on soybean, corn, sugar cane, pasture and fruit crops (Johann et al. 2012; Risso et al. 2012; Santi et al. 2012; Vicente et al. 2012; Victoria et al. 2012; Gupta et al. 2013; Picoli et al. 2013; Zaman-Allah et al. 2015; Vergara-Díaz et al. 2016), few studies have employed these techniques on vegetables, and even fewer on lettuce.

The fresh lettuce mass results in the present study were superior to those found by Mógor and Câmara (2007) and Santos et al. (2009) and similar to those of several other studies (Blat et al. 2011; Diamante et al. 2013; Suinaga et al. 2013; Ziech et al. 2014; Brzezinski et al. 2017). This suggests that the lettuce lines examined in the present study have reached market standards.

The stem diameter findings in the present study corroborate those of Brzezinski et al. 2017. Nevertheless, differences in stem diameter between genotypes may be associated with variations in solar radiation and temperature (Galbiatti et al. 2007).

Differences in the agronomic performance of lettuce cultivars due to differences in environmental conditions have been recorded in various regions of Brazil (Diamante et al. 2013; Aquino et al. 2014). Santos et al. (2009) evaluated 15 commercial cultivars of crisphead lettuce in Cáceres, MT, Brazil, and found lower leaf numbers than those in the present study, while Diamante et al. (2013) found similar values to those of the present study.

Plant diameter is a commercially important characteristic. The results found in the present study corroborate those obtained by Diamante et al. (2013) who evaluated the agronomic performance of four cultivars in five distinct environments.

Environmental conditions, especially light, have been shown to directly interfere with anthocyanin expression (Galbiatti et al. 2007; Sala and Costa 2016; Liu et al. 2018), which explains why the genotypes examined in the current study did not differ regarding leaf temperature and anthocyanin content. This also suggests that environmental conditions were similar throughout all treatments. It is noteworthy that anthocyanin content is influenced by environmental and genetic factors. Zhang et al. (2016) identified 34 genes involved in the anthocyanin metabolic pathway, which implies quantitative gene expression that does not fit a normal distribution, but rather a Poisson distribution.

Bolting is another important consideration for lettuce breeding. Lines that have longer periods between sowing and flower tassel production show a greater tolerance to early bolting. These characteristics are desirable for commercial lettuce cultivation. Therefore, the lines showing this character in the present study can be classified as tropically adapted.

Lettuce lines with greater SPAD/carotenoid levels than that of the commercial cultivar Grand Rapids were classified as biofortified. Several studies have shown that the SPAD index is an efficient indicator of leaf chlorophyll levels (Klooster et al. 2012). Moreover, chlorophyll levels are highly correlated with carotenoid concentrations in lettuce (Cassetari et al. 2015). Thus, SPAD can be used to indirectly evaluate carotenoid content in lettuce.

Comparisons between mean measures of agronomic performance and multivariate analysis can help plant breeders make better decisions regarding lettuce breeding. Furthermore, using dissimilarity measures to separate genotypes into distinct groups can help breeders in the selection of parent plants (Araújo et al. 2016).

Genetic variability among genotypes was essential for validating the use of image phenotyping. This technique could be used in several stages of plant breeding such as genomic selection, gene prospecting, germplasm characterization, quantitative trait loci mapping and phenotypic selection for yield, resistance to abiotic and biotic stress, and biofortified foods (Araus and Cairns 2014; Fritsche-Neto and Borém 2016). 


\section{CONCLUSION}

The germplasm bank evaluated in this study was genetically diverse, especially regarding carotenoid/SPAD levels. Image phenotyping was successfully used to detect different carotenoid/SPAD levels in the germplasm and could be useful in breeding programs. The results of this study can be used to predict the nutritional values of the carotenoid content in lettuce leaves before commercialization.

\section{ACKNOWLEDGMENTS}

The authors would like to express their gratitude to the Conselho Nacional de Desenvolvimento Científico e Tecnológico (CNPq), Coordenação de Aperfeiçoamento de Pessoal de Nível Superior (Capes), Fundação de Amparo à Pesquisa do Estado de Minas Gerais (Fapemig), Universidade Federal de Uberlândia (UFU) and UFU’s Pró-Reitoria de Pós-Graduação e Pesquisa for their financial and administrative support.

\section{AUTHOR'S CONTRIBUTION}

Investigation, Maciel G. M.; Gallis R B. A.; Barbosa R. L.; Pereira, L. M.; Siquieroli A. C. S. and Peixoto J. V. M.; Writing Original Draft, Maciel G. M.; Siquieroli A. C. S. and Peixoto J. V. M.; Writing - Review and Editing: Gallis R. B. A.; Barbosa R. L. and Pereira, L. M.; Funding Acquisition: Maciel G. M.; Gallis R B. A.; Barbosa R. L.; Pereira, L. M.; Siquieroli A. C. S.; Peixoto J. V. M.

\section{REFERENCES}

[SISMET] Sistema de Monitoramento Meteorológico - Cooxupé. (2018). Monte Carmelo. [Accessed Dec. 11, 2019]. Available at: http:// sismet.cooxupe.com.br:9000/

Alós, E., Rodrigo, M. J. and Zacarias L. (2016). Manipulation of carotenoid content in plants to improve human health. In C. Stange (Ed.). Carotenoids in Nature: Biosynthesis, Regulation and Function (p. 311-343). Cham: Springer. https://doi.org/10.1007/978-3-319-39126-7_12

Aquino, C. R., Seabra Júnior, S., Camili, E. C., Diamante, M. S. and Pinto, E. S. C. (2014). Produção e tolerância ao pendoamento de alfaceromana em diferentes ambientes. Revista Ceres, 61, 558-566. https://doi.org/10.1590/0034-737X201461040016

Araújo, J. C., Telhado, S. F. P., Sakai, R. H., Ledo, C. A. S. and Melo, P. C. T. (2016). Univariate and multivariate procedures for agronomic evaluation of organically grown tomato cultivars. Horticultura Brasileira, 34, 374-380. https://doi.org/10.1590/S0102-05362016003011

Araus, J. L. and Cairns, J. E. (2014). Field high-throughput phenotyping: the new crop breeding frontier. Trends in Plant Science, 19, 52-61. https://doi.org/10.1016/j.tplants.2013.09.008

Blat, S. F., Sanchez, S. V., Araújo, J. A. C. and Bolonhezi, D. (2011). Desempenho de cultivares de alface crespa em dois ambientes de cultivo em sistema hidropônico. Horticultura Brasileira, 29, 135-138. https://doi.org/10.1590/S0102-05362011000100024

Brisson, N., Gate, P., Gouache, D., Charmet, G., Oury, F.-X. and Huard, F. (2010). Why are wheat yields stagnating in Europe? A comprehensive data analysis for France. Field Crops Research, 119, 201-212. https://doi.org/10.1016/j.fcr.2010.07.012

Brzezinski, C. R., Abati, J., Geller, A., Werner, F. and Zucareli, C. (2017). Produção de cultivares de alface americana sob dois sistemas de cultivo. Revista Ceres, 64, 83-89. https://doi.org/10.1590/0034-737×201764010012 
Cassetari, L. S., Gomes, M. S., Santos, D. C., Santiago, W. D., Andrade, J., Guimarães, A. C., Souza, J. A., Cardoso, M. G., Maluf, W. R. and Gomes, L. A. (2015). $\beta$-carotene and chlorophyll levels in cultivars and breeding lines of lettuce. Acta Horticulturae, 1083, $469-474$. https://doi.org/10.17660/ActaHortic.2015.1083.60

Cruz, C. D. (2013). GENES - a software package for analysis in experimental statistics and quantitative genetics. Acta Scientiarum. Agronomy. 35, 271-276. https://doi.org/10.4025/actasciagron.v35i3.21251

Cruz, C. D., Regazzi, A. J. and Carneiro, P. C. S. (2014). Modelos biométricos aplicados ao melhoramento genético. Viçosa: Editora UFV. Dhondt, S., Wuyts, N. and Inzé, D. (2013). Cell to whole-plant phenotyping: the best is yet to come. Trends in Plant Science, 18, 428-439. https://doi.org/10.1016/j.tplants.2013.04.008

Diamante, M. S., Seabra Júnior, S., Inagaki, A. M., Silva, M. B. and Dallacort, R. (2013). Produção e resistência ao pendoamento de alfaces tipo lisa cultivadas sob diferentes ambientes. Revista Ciência Agronômica, 44, 133-140. https://doi.org/10.1590/S1806-66902013000100017

Filgueira, F. A. R. (2013). Novo manual de olericultura: agrotecnologia moderna na produção e comercialização de hortaliças. Viçosa: Editora UFV.

Francis, F. J. (1982). Analysis of anthocyanins. In P. Markakis (Ed.). Anthocyanins as food colors (p. 181-207). London: Academic Press. https://doi.org/10.1016/B978-0-12-472550-8.50011-1

Fritsche-Neto, R. and Borém, A. (2016). Fenômica: como a fenotipagem de próxima geração está revolucionando o melhoramento de plantas. Viçosa: Editora UFV.

Galbiatti, J. A., Cavalcante, I. H. L., Ribeiro, A. G. and Beckmann, M. Z. (2007). Fertilização e qualidade da água de irrigação no crescimento e desenvolvimento da alface. Scientia Agraria, 8, 185-192. https://doi.org/10.5380/rsa.v8i2.8368

Gupta, S. D., Ibaraki, Y. and Pattanayak, A. K. (2013). Development of a digital image analysis method for real-time estimation of chlorophyll content in micropropagated potato plants. Plant Biotechnology Reports, 7, 91-97. https://doi.org/10.1007/s11816-012-0240-5

Johann, J. A., Rocha, J. V., Duft, D. G. and Lamparelli, R. A. C. (2012). Estimativa de áreas com culturas de verão no Paraná, por meio de imagens multitemporais EVI/Modis. Pesquisa Agropecuária Brasileira, 47,1270-1278. https://doi.org/10.1590/S0100-204X2012000900015

Kimura, M. and Rodriguez-Amaya, D. B. A. (2002). A scheme for obtaining standards and HPLC quantification of leafy vegetable carotenoids. Food Chemistry, 78, 389-398. https://doi.org/10.1016/S0308-8146(02)00203-0

Klooster, W. S., Cregg, B. M., Fernandez, R. T. and Nzokou, P. (2012). Growth and physiology of deciduous shade trees in response to controlled-release fertilizer. Scientia Horticulturae, 135, 71-79. https://doi.org/10.1016/j.scienta.2011.12.009

Kyratzis, A. C., Skarlatos, D. P., Menexes, G. C., Vamvakousis, V. F. and Katsiotis, A. (2017). Assessment of vegetation indices derived by UAV imagery for durum wheat phenotyping under a water limited and heat stressed Mediterranean environment. Frontiers in Plant Science, 8, 1-14. https://doi.org/10.3389/fpls.2017.01114

Liu, Y., Tikunov, Y., Schouten, R. E., Marcelis, L. F. M., Visser, R. G. F. and Bovy, A. (2018). Anthocyanin biosynthesis and degradation mechanisms in Solanaceous vegetables: a review. Frontiers in Plant Science, 6, 1-17. https://doi.org/10.3389/fchem.2018.00052

Maciel, G. M., Siquieroli, A. C. S., Gallis, R. B. A., Pereira, L. M. and Sales, V. F. (2019a). Programa de computador BG a Biofort. Depositante: Universidade Federal de Uberlândia. BR512019002403-6. Depósito: 01 fev. 2019. Concessão: 23 out. .

Maciel, G. M., Gallis, R. B. A., Barbosa, R. L., Pereira, L. M., Siquieroli, A. C. S. and Peixoto, J. V. M. (2019 b). Image phenotyping of inbred red lettuce lines with genetic diversity regarding carotenoid levels. International Journal of Applied Earth Observation and Geoinformation, 81, 154-160. https://doi.org/10.1016/j.jag.2019.05.016 
Makanza, R., Zaman-Allah, M., Cairns, J. E., Magorokosho, C., Tarekegne, A., Olsen, M. and Prasanna, B. M. (2018). High-throughput phenotyping of canopy cover and senescence in maize field trials using aerial digital canopy imaging. Remote Sensing, 10, 1-13. https:// doi.org/10.3390/rs10020330

Mantel, N. (1967). The detection of disease clustering and a generalized regression approach. Cancer Research, 27, $209-220$.

Mógor, A. F. and Câmara, F. L. A. (2007). Produção de alface no sistema orgânico em sucessão a aveia preta, sobre a palha, e diferentes coberturas do solo. Scientia Agraria, 8, 239-245. https://doi.org/10.5380/rsa.v8i3.9535

Picoli, M. C. A., Lamparelli, R. A. C., Sano, E. E., Mello, J. R. B. and Rocha, J. V. (2013). Effect of sugarcane-planting row directions on ALOS/PALSAR satellite images. GIScience \& Remote Sensing, 50, 349-357. https://doi.org/10.1080/15481603.2013.808457

Risso, J., Rizzi, R., Rudorff, B. F. T., Adami, M., Shimabukuro, Y. E., Formaggio, A. R. and Epiphanio, R. D. V. (2012). Índices de vegetação Modis aplicados na discriminação de áreas de soja. Pesquisa Agropecuária Brasileira, 47, 1317-1326. https://doi.org/10.1590/ S0100-204X2012000900017.

Rocha, D. S. and Reed, E. (2014). Pigmentos naturais em alimentos e sua importância para a saúde. Estudos Vida e Saúde, $41,1,76-85$. Sala, F. C., Costa, C. P., Teixeira, L. D., Fabri, E. G. and Blat, S. F. (2008). Reação de cultivares de alface a Thielaviopsis basicola. Horticultura Brasileira, 26, 398-400. https://doi.org/10.1590/S0102-05362008000300021

Sala, F. C. and Costa, C. P. (2012). Retrospectiva e tendência da alfacicultura brasileira. Horticultura Brasileira, 30, 187-194. https://doi. org/10.1590/S0102-05362012000200002

Sala, F. C. and Costa, C. P. (2016). Melhoramento de alface. In C. Nick and A. Borém (Eds.). Melhoramento de hortaliças (p. 95-127). Viçosa: Editora UFV.

Santi, A. L., Amado, T. J. C., Cherubin, M. R., Martin, T. N., Pires, J. L., Flora, L. P. D. and Basso, C. J. (2012). Análise de componentes principais de atributos químicos e físicos do solo limitantes à produtividade de grãos. Pesquisa Agropecuária Brasileira, 47, $1346-1357$. https://doi.org/10.1590/S0100-204X2012000900020

Santos, C. L., Seabra Junior, S., Lalla, J. G., Theodoro, V. C. A. and Nespoli, A. (2009). Desempenho de cultivares de alface tipo crespa sob altas temperaturas em Cáceres-MT. Agrarian, 2, 87-98.

Silva, S. and Mura, J. (2016). Tratado de alimentação, nutrição e dietoterapia. São Paulo: Editora Payá.

Singh, D. (1981). The relative importance of characters affecting genetic divergence. Indian Society of Genetics \& Plant Breeding, 41, 237-245.

Siquieroli, A. C. S., Maciel, G. M., Pereira, L. M., Gallis, R. B. A. and Sales, V. F. (2019). BG a BIOFORT. BR Patent No. $512019002403-6$. Uberlândia, SP: Universidade Federal de Uberlândia.

Sousa, C. S. D., Bonetti, A. M., Goulart Filho, L. R., Machado, J. R. A., Londe, L. N., Baffi, M. A., Ramos, R. G., Vieira, C. U. and Kerr, W. E. (2007). Divergência genética entre genótipos de alface por meio de marcadores AFLP. Bragantia, 66, 11-16. https://doi.org/10.1590/ S0006-87052007000100002

Sousa, C. A. F., Cunha, B. A. D. B., Martins, P. K., Molinari, H. B. C., Kobayashi, A. K. and Souza Júnior, M. T. (2015). Nova abordagem para a fenotipagem de plantas: conceitos, ferramentas e perspectivas. Revista Brasileira de Geografia Física, 8, SI, 660-672. https:// doi.org/10.5935/1984-2295.20150022

Suinaga, F. A., Boiteux, L. S., Cabral, C. S. and Rodrigues, C. S. (2013). Comunicado Técnico, 89: Métodos de avaliação do florescimento precoce e identificação de fontes de tolerância ao calor em cultivares de alface do grupo varietal crespa. Brasília: Embrapa Hortaliças. [Accessed Dec. 11, 2019]. Available at: https://www.infoteca.cnptia.embrapa.br/bitstream/doc/956376/1/cot89.pdf 
Tripodi, P., Massa, D., Venezia, A. and Cardi, T. (2018). Sensing technologies for precision phenotyping in vegetable crops: current status and future challenges. Agronomy, 8, 1-24. https://doi.org/10.3390/agronomy8040057

Vergara-Díaz, O., Zaman-Allah, M. A., Masuka, B., Hornero, A., Zarco-Tejada, P., Prasanna, B. M., Cairns, J. E. and Araus, J. L. (2016). A novel remote sensing approach for prediction of maize yield under different conditions of nitrogen fertilization. Frontiers in Plant Science, 7 , 1-13. https://doi.org/10.3389/fpls.2016.00666

Vicente, L. E., Gomes, D., Victoria, D. C., Garçon, E. A. M., Bolfe, É. L. andrade, R. G. and Silva, G. B. S. (2012). Séries temporais de NDVI do sensor SPOT Vegetation e algoritmo SAM aplicados ao mapeamento de cana-de-açúcar. Pesquisa Agropecuária Brasileira, 47, 13371345. https://doi.org/10.1590/S0100-204X2012000900019

Victoria, D. C., Paz, A. R., Coutinho, A. C., Kastens, J. and Brown, J. C. (2012). Cropland area estimates using Modis NDVI time series in the state of Mato Grosso, Brazil. Pesquisa Agropecuária Brasileira, 47, 1270-1278. https://doi.org/10.1590/S0100-204X2012000900012

Walter, A., Liebisch, F. and Hund, A. (2015). Plant phenotyping: from bean weighing to image analysis. Plant Methods, 11, 1-11. https:// doi.org/10.1186/s13007-015-0056-8

Yang, G., Liu, J., Zhao, C., Li, Z., Huang, Y., Yu, H., Xu, B., Yang, X., Zhu, D., Zhang, X., Zhang, R., Feng, H., Zhao, X., Li, Z., Li, H. and Yang, H. (2017). Unmanned aerial vehicle remote sensing for field-based crop phenotyping: current status and perspectives. Frontiers in Plant Science, 8, 1-26. https://doi.org/10.3389/fpls.2017.01111

Zaman-Allah, M., Vergara, O., Araus, J. L., Tarekegne, A., Magorokosho, C., Zarco-Tejada, P. J., Hornero, A., Albá, A. H., Das, B., Craufurd, P., Olsen, M., Prasanna, B. M. and Cairns, J. (2015). Unmanned aerial platform-based multi-spectral imaging for field phenotyping of maize. Plant Methods, 11, 1-10. https://doi.org/10.1186/s13007-015-0078-2

Zhang, Y. Z., Xu, S. Z., Cheng, Y. W., Ya, H. Y. and Han, J.M. (2016). Transcriptome analysis and anthocyaninrelated genes in red leaf lettuce. Genetics and Molecular Research, 15, 1-11. https://doi.org/10.4238/gmr.15017023

Ziech, A. R. D., Conceição, P. C., Luchese, A. V., Paulus, D. and Ziech, M. F. (2014). Cultivo de alface em diferentes manejos de cobertura do solo e fontes de adubação. Revista Brasileira de Engenharia Agrícola e Ambiental, 18, 948-954. https://doi.org/10.1590/1807-1929/ agriambi.v18n09p948-954 